УДК 030:02

\title{
Сергій Зворський
}

кандидат історичних наук, старший науковий співробітник,

Національна парламентська бібліотека України

\section{«Українська бібліотечна енциклопедія» — від задуму до практичної реалізації}

Розвиток бібліотечної справи в Україні, починаючи з 1991 р., характеризується вивільненням від ідеологем, типових для соціалістичного суспільства, динамічним оновленням теоретичних концепцій та започаткуванням нових напрямів практичної діяльності, покликаних оптимальне функціонування книгозбірень в нових соціальних і економічних реаліях. Розширюється і вдосконалюється терміносистема бібліотечної справи, запроваджуються інноваційні напрями та інформаційні технології діяльності бібліотек як соціальних інститутів, відбувається інтеграція бібліотечної сфери України у світовий інформаційний простір. Можна говорити про якісне вдосконалення бібліотечної сфери України як складної інформаційної системи і в теоретичній і в практичній площинах.

Україна по праву може вважатися однією з найрозвиненіших бібліотечних держав світу: вона має тисячолітню, починаючи з часів Ярослава Мудрого, традицію засновування книгозбірень як скарбниць знань, накопичених людством; розвинену сучасну інфраструктуру — широку мережу бібліотек - наукових, публічних, навчальних, юнацьких, дитячих, спеціалізованих, серед яких є кілька книгозбірень, що входять до числа найбільших у світі; вибудовану систему підготовки і підвищення кваліфікації бібліотечних кадрів; наукові школи бібліотекознавців, бібліографознавців, документознавців; різноманітні фахові періодичні і продовжувані видання; зрештою, Україна інтегрована у міжнародне бібліотечне співтовариство. Розвиток бібліотечної справи і наук документно-комунікаційного циклу в Україні, фахова підготовка провідних співробітників наукових книгозбірень і викладачів профільних ВНЗ нині досягли такого рівня, коли конче постає потреба в систематизації, узагальненні та популяризації суми знань і здобутків у бібліотечній сфері у максимально компактній і загальнодоступній формі. Реалізація такого завдання можлива, зокрема, шляхом укладання спеціальної галузевої енциклопедії.

У світі лише деякі країни мають досвід підготовки і видання бібліотечних енциклопедій - США, Великобританія, Польща, Росія, Німеччина. Прикметно, що майже всі вони входять до першої десятки найбільш економічно розвинених країн світу. В Україні питання про створення власної бібліотечної енциклопедії було ініційоване Національною парламентською бібліотекою України (НПБУ). Починаючи з 2010 р., НПБУ власними силами розпочала практичну реалізацію наукового проекту «Українська бібліотечна енциклопедія» (УБЕ). У складі відділу науково-дослідної роботи НПБУ створено сектор енциклопедичних дослід- 
жень, на який покладено завдання: розробити проект концепції УБЕ; сформувати Словник енциклопедії; координувати роботу структурних підрозділів НПБУ 3 підготовки статей; взаємодіяти з іншими книгозбірнями та авторами, що працюють поза НПБУ; здійснювати наукове редагування статей тощо. Проект концепції «Української бібліотечної енциклопедії» пройшов апробацію у структурних підрозділах Національної парламентської бібліотеки України, був оприлюднений на сторінках фахового журналу «Бібліотечна планета» [1] для загального ознайомлення і отримання конструктивних зауважень і пропозицій, схвалений Вченою радою НПБУ. Для авторів, що пишуть статті для УБЕ, наступного року було підготовлено і видано відповідні «Методичні рекомендації» [2], в яких викладено основні форми і методичні прийоми опрацювання і підготовки матеріалів для УБЕ, технічні вимоги, що висуваються до текстів, запропоновано типові схеми статей у рамках тих чи інших тематичних блоків.

Основна мета «Української бібліотечної енциклопедії» (далі — УБЕ) — peпрезентація за засадах об'єктивності, науковості аргументованості, бібліотечної справи в Україні в ії сучасних адміністративно-територіальних кордонах як важливої складової української культури, науки, освіти, наукове узагальнення й систематизація знань, накопичених у вітчизняній бібліотечній сфері. Важливою метою укладачі УБЕ вважають збереження і примноження національних традицій і особливостей в організації діяльності українських бібліотек, що мають тисячолітню історію хранителів цивілізаційних здобутків. Наприклад, на відміну від російської «Библиотечной энциклопедии» [3], де зроблено спробу схарактеризувати стан бібліотечної справи у більшості країн світу та подати відомості про найвідоміших представників світового бібліотечного руху, до УБЕ не включено інформацію про бібліотечну справу та іiі видатних репрезентантів поза межами України (виняток - статті про вихідців з України та бібліотечну справу у найбільших осередках української діаспори, скажімо, про Українську бібліотеку ім. Симона Петлюри в Парижі та їі багаторічного керівника Івана Рудичіва). УБЕ також подає статті про міжнародні організації та програми, що пов'язані з бібліотечною справою і в роботі яких брала чи бере участь Україна (ЮНЕСКО, ІФЛА Міжнародна рада бібліотечних асоціацій, БАЄ - Бібліотечна асамблея Свразії, «Пам'ять століть» та ін.).

Первісно передбачалося, що УБЕ буде однотомним спеціалізованим науково-популярним виданням обсягом 100-120 авт. арк. і накладом в 2,5-3 тис. примірників. Загалом в УБЕ планувалося вмістити близько 1200-1500 статей. 3 огляду на обсяг УБЕ більшість статей мали бути короткими, у формі гасел-визначень, а кількість ілюстрацій — обмеженою. На це авторів статей націлювали і вже згадувані «Методичні рекомендації» [2].

Навесні 2014 р. керівництво НПБУ з урахуванням непростої економічної, політичної, військової ситуації в Україні прийняло принципове рішення про переведення наукового проекту «Українська бібліотечна енциклопедія» 3 друкованого в електронний формат. Таке рішення вважаємо цілком виправданим, тим більше що тенденція переведення енциклопедій в електронний формат стає світовим трен- 
дом. У Росії саме з економічних причин (відсутність коштів на друкування) вихід у світ «Библиотечной энциклопедии» [2] відбувся з трирічним запізненням, хоча економіка РФ з-за постійного зростання цін на експортовані енергоресурси на початку XXI ст. перебувала у набагато кращому стані, ніж українська. Через це, як визнають і самі укладачі «Библиотечной энциклопедии», певна частина інформації, яку викладено у виданні, вже на час друкування виявилась застарілою. Не чекаючи повного завершення роботи над УБЕ, з червня 2015 р. окремі статті вже виставлені для загального безкоштовного користування на сайті НПБУ за адресою: http://ube.nplu.org/, де в меню головної сторінки є окрема опція «Українська бібліотечна енциклопедія». Відтепер відбувається постійний процес послідовного наповнення зазначеного інтернет-ресурсу новими статтями.

Переваги УБЕ в електронному форматі є очевидними: загальнодоступність цього інформаційно-довідкового ресурсу (це суттєвий чинник в умовах перманентних обмежених асигнувань на комплектування публічних і наукових книгозбірень), оперативність в інформування користувачів, відсутність затрат на друкування енциклопедії та обмежень в обсязі статей та ілюстративних матеріалів, можливість виставлення статей з більшим обсягом тексту та ілюстративних матеріалів, постійне внесення оновлених статистичних, біографічних, фактографічних, бібліографічних відомостей тощо. Застосування у текстах ключових термінів (ï виділяють кольором) уможливлює за потреби зручний миттєвий перехід до інших статей. При необхіності можна здійснювати автоматичний переклад статей на інші мови світу за допомогою відповідних сервісів в мережі Інтернет. У перспективі цілком можливе перетворення УБЕ в мультимедійний ресурс, із залученням різних відео- та аудіоматеріалів.

За цільовим та читацьким призначенням УБЕ адресовано широкому колу читачів: фахівцям бібліотечної та інформаційної сфер, інших напрямів соціогуманітарної діяльності, науковцям, викладачам вищих навчальних закладів, аспірантам, студентам, держслужбовцям, користувачам бібліотек тощо. Знання, акумульовані в УБЕ, покликані давати відповіді на різноманітні питання наукового, освітнього і практичного характеру. Основними критеріями, що покладаються в основу створення «УБЕ», $є$ актуальність, універсальність, науковість, вичерпність та достовірність інформації. Актуальність і суспільна затребуваність підготовки енциклопедії передусім пов'язані з утвердженням інтелектуальної незалежності української нації і держави, усталенням законодавчої і нормативної бази діяльності бібліотек, насамперед прийняттям Закону України «Про бібліотеки і бібліотечну справу» №32/95 від 27.01.1995 р. та його останньої редакції від 21.05.2009 p., інших законів України в інтелектуальній сфері, запровадженням системи державних стандартів України, що стосуються діяльності бібліотек тощо. Критерії універсальності та вичерпності ставлять перед авторами й укладачами УБЕ завдання максимально всебічного розкриття в концентрованій формі основних понять бібліотечної справи та частково суміжних сфер діяльності (права, економіки, інформатики, книгознавства, книжкової справи, архівознавства, документознавства, соціології, психології, педагогіки тощо). 
Застосування критерію науковості вимагає від авторів, укладачів, редакторів УБЕ дотримання таких принципів: максимальної об'єктивності у висвітленні стану бібліотечної справи, відстороненості від власних та запозичених упереджених трактувань і оцінок явищ і подій, раціоналістичної (достатньої) обгрунтованості, коли зміст окремої статті має бути виваженим, збалансованим, вичерпним, грунтуватися на самокритичності і водночас не містити другорядних, несуттєвих деталей; особливої організації, системності у викладі знань про об’ єкт, що описується у статті за певною схемою. Достовірність визначає ступінь об'єктивного, точного відображення подій, фактів, що мали місце в бібліотечній справі України. За структурою основного тексту УБЕ формується на основі окремих статей (гасел) різного обсягу і за алфавітним принципом розташування матеріалів. До енциклопедії включаються статті про: історичне минуле та сучасний стан бібліотечної справи в Україні в цілому та в окремих регіонах; мережі бібліотек за різними типологічними ознаками; великі бібліотеки — науково-методичні, бібліографічні, інформаційні центри у своїй галузі; науково-дослідну, бібліографічну, методичну діяльність бібліотек; бібліотечні фонди; користувачів бібліотек та їх вивчення; бібліотечні кадри; видатних діячів бібліотечної справи; окремі питання суміжних наук та дисциплін (документознавство, книгознавство, інформатика, архівна справа, соціологія); термінологічні аспекти, пов'язані з бібліотечною справою, бібліографією, інформатикою. Загалом у процесі укладання робочого і постійно коригованого сло́вника УБЕ (наразі він включає близько 1300 гасел) сформовано 11 тематичних розділів (блоків), більшість з яких перелічено вище.

Найбільш складними i багатоаспектними вбачаються статті історикорегіонального змісту, об’єднані в тематичний блок «N-ська область. Бібліотечна справа». Незважаючи на те, що майже в усіх областях України в останні 20-25 років помітно активізувалась науково-дослідна робота з вивчення історії окремих бібліотек та бібліотечної справи на рівні окремих районів і міст, в цілому на обласному рівні узагальнюючі дослідження з цієї теми досі не проводились, відповідно бракує й напрацювань, наукових публікацій, баз даних як джерельної бази для написання розгорнутої статті про зародження, становлення, розвиток і перспективи бібліотечної справи, мереж книгозбірень різного відомчого підпорядкування в тій чи іншій області. 3 урахуванням «енциклопедичного буму» в Україні, появою окремих галузевих енциклопедій і енциклопедичних словників соціогуманітарного спрямування, зокрема з книгознавства, інформатики тощо, в УБЕ відображено головним чином лише основні поняття цих та інших суміжних з бібліотечною справою галузей.

Залежно від типу й змісту статей вони мають різний обсяг. Великими (до 0,5 авт. арк.) є узагальнювальні статті, що відображають поняття, яким властиві багатогранність характеристик, ієрархічність структури, широкий соціальний чи історичний контекст. Середніми за обсягом (до 0,25 авт. арк.) є статті оглядового чи довідкового характеру. Статті-дефініції, завдання яких дати роз'яснення певного терміна, є короткими, до 5 речень. До всіх узагальнювальних та до більшості оглядових і довідкових статей додано пристатейну бібліографію. Хоча УБЕ започат- 
ковувалась за ініціативою НПБУ і силами їі співробітників, проте укладачі енциклопедії прагнуть залучити до написання статей якомога більшу кількість авторів, насамперед тих, хто має досвід практичної, наукової і публікаційної діяльності, з усіх областей України. У цьому напрямі проводять активну роз'яснювальну роботу, яка вже має позитивні результати. Активно надходять статті від представників професорсько-викладацького складу Харківської державної академії культури, Рівненського державного гуманітарного університету, провідних спеціалістів національних, великих наукових книгозбірень, обласних універсальних наукових бібліотек. Тому вже зараз можна стверджувати, що УБЕ стане дійсно загальноукраїнською енциклопедією.

Як свого часу вихід у світ загальних (універсальних) енциклопедій, їх обсяг і глибина наповнення свідчив про рівень розвитку знань та інтелектуальний потенціал держави і певною мірою був мірилом їі престижу й авторитету, так і галузеві енциклопедії нині є свідченням належного рівня розвитку певної суспільної сфери. Тому реалізацію наукового проекту під назвою «Українська бібліотечна енциклопедія» варто розглядати як прагнення бібліотечної спільноти держави зробити істотний внесок у наукове узагальнення накопиченої суми знань у бібліотечній сфері, уніфікацію бібліотечно-інформаційної термінології, розвиток міжнародних культурних та наукових зв'язків.

Зрештою, УБЕ можна розглядати одним зі складників долучення України до процесів глобалізації та уніфікації бібліотечно-інформаційної сфери, а також свідченням зрілості бібліотек як соціокультурних інститутів, бібліотечної справи в державі і іï виходу на якісно новий рівень розвитку. УБЕ також сприятиме утвердженню позитивного міжнародного іміджу України як держави з багатими культурними традиціями і здобутками.

\section{ЛІТЕРАТУРА}

1. Концепція «Української бібліотечної енциклопедії» // Бібліотечна планета. — 2011. № 1. - C. 30-32. — http://profy.nplu.org/file/lp-51.pdf/.

2. Методичні рекомендації для авторів «Української бібліотечної енциклопедії» / Уклад.: С. Л. Зворський, Л. М. Любаренко, Г. П. Нелипа. - К., 2012. — 28 с. — http://nplu.org/ storage/doc/Osn.doc/.

3. Библиотечная энциклопедия / Глав. ред. Ю. А. Гриханов. — М., 2007. - 1300 с. 